\title{
Analysis of the socio-environmental vulnerability of black and Caucasian pregnant women in Salvador, Bahia, Brazil to the occurrence of microcephaly associated with the congenital syndrome of zika virus
}

\author{
Karine de Souza Oliveira Santana, ${ }^{1}$ Argemiro D'Oliveira Júnior, ${ }^{2}$ Liliane de Jesus Bittencourt, ${ }^{3}$ \\ Marta Mariana Nascimento, ${ }^{4}$ Isabel Cristina Santos Guimarães, ${ }^{5}$ Ênio Soares, ${ }^{6}$ \\ Moara de Santana Martins Rodgers, ${ }^{7}$ Asha Nicole Fradkin ${ }^{8}$ \\ ${ }^{1}$ Federal University of Bahia, Bahia School of Medicine and Public Health, Disease Monitoring Laboratory \\ by the Geographic Information System, Research, Gender and Health Research Center, Bahia; ${ }^{2}$ Federal \\ University of Bahia, Department of Clinical Medicine; ${ }^{3}$ Federal University of Bahia, Department of \\ Nutrition Sciences, Nucleus of Study and Research in Race, Gender and Health; ${ }^{4}$ Federal University of \\ Bahia, Laboratory of Disease Monitoring by the Geographic Information System; ${ }^{5}$ Municipal Health \\ Secretariat of Salvador, Bahia, Zoonoses Control Center; ${ }^{6}$ Municipal Health Secretariat of Salvador, Bahia, \\ State Health Secretariat of Bahia, Epidemiological Surveillance Board, Bahia, Brazil; ${ }^{7}$ NASA ROSES \\ Postdoctoral Researcher, Louisiana State University, School of Veterinary Medicine, Department of \\ Pathobiological Sciences, Geospatial Health Laboratory; ${ }^{8}$ University Emory, Atlanta, USA
}

\begin{abstract}
To understand the occurrence of the Congenital Zika Syndrome (CZS), the living conditions of pregnant individuals must be considered in order to identify factors and areas of risk. An intersectional approach provides an understanding of the vulnerabilities to which Black women are subjected. To that end, we present an overview of the spatio-temporal distribution of confirmed cases of microcephaly associated with CZS during the 2015-2016 period in Salvador, Bahia, Brazil based on a survey of
\end{abstract}

Correspondence: Karine de Souza Oliveira Santana, R. Dr. Augusto Viana, S/n - Canela, Salvador - BA, 40110-060.

Tel.: +55 71 3283-8251/+55 $7199205-5159$

E-mail: kasousan@yahoo.com.br

Key Words: Pregnant; Zika virus; Intersectionality; Brazil.

Conflict of Interests: The authors declare no potential conflicts of interest.

Ethical Aspects: The protocol of this study was approved by the Committee of Ethics in Research of the School of Medicine at the Federal University of Bahia.

Received for publication: 1 July 2019.

Accepted for publication: 14 February 2020.

(C) Copyright: the Author(s), 2020

Licensee PAGEPress, Italy

Geospatial Health 2020; 15:795

doi:10.4081/gh.2020.795

This article is distributed under the terms of the Creative Commons Attribution Noncommercial License (CC BY-NC 4.0) which permits any noncommercial use, distribution, and reproduction in any medium, provided the original author(s) and source are credited.
Black and Caucasian, pregnant women seen through the intersectional lens of race and class. To consider the confirmed cases of microcephaly and other neurological anomalies associated with CZS, a Living Condition Index (LCI) was utilized to rate the socio-environmental vulnerability of pregnant women. There was less information in the notification records with regard to Black, pregnant women resulting in fewer examinations. Twelve, highrisk areas for Black, pregnant women were identified but only two for Caucasian women. CZS cases referred to Black, pregnant women were found to be concentrated in census sectors with a low $(31.6 \%)$ and very low $(34.5 \%)$ LCI, while those referred to Caucasian, pregnant women were concentrated in areas with a high (35.6\%) and intermediate $(29.4 \%)$ LCI. The study concludes that inequities in health expose different population groups to different forms of illnesses, and institutional racism solidifies scenarios of exclusion. In this sense, Black women experiences manifest directly in their health. Confrontation with arboviruses requires the implementation of inter-institutional policies aimed at overcoming discriminatory practices of exposure.

\section{Introduction}

Enumeration of indicators associated with socioeconomic variables have been carried out during the last decades for various living conditions of the population to understand the relationship between social, biological, economic and environmental aspects in the patterns of the health or illness in a determined territory. Utilization of such indicators allow a reliable evaluation of living conditions of distinct populations, favouring the elaboration of public policies to achieve better equity in health by indicating gaps in health care that needs to be closed (Paim, 2003). To guide this approach social inequalities in health are studied through the evaluation of the association between living conditions, access to health services and comprehensive care, while taking the epidemiological situation in the neighbourhood into account. 
Exposition to various illnesses differs between population groups due to factors, such as the immediate environment, cultural context as well as genetics. Thus, we have the pattern of social reproduction and maintenance of conditions that promote disease and injury or sanity, manifested through the various forms of oppression characterized by class division, race or gender. (Oliveira, 2004). Environmental and social conditions which favour the permanent circulation of Aedes aegypti in Brazilian, together with the resident population under attack of infections transmitted by this mosquito, configure an associated pattern of vulnerabilities. Johansen (2014), in a study carried out in a county of São Paulo, presents evidence that the incidence rate of dengue is four times higher for Black people, which emphasizes that all inhabitants are not under the same risk.

The Zika Virus (ZIKV) has been present in American and Caribbean countries for more than 50 years causing occasional outbreaks, but without epidemiological impact. The US National Library of Medicine/National Institutes of Health database of medical articles (PubMed) includes about 30 million references. Out of these, 112 articles mention the earliest known circulation of the virus from 1952 to 2014, highlighting the cases in French Polynesia and Pacific Islands in 2014, and in Yap, an island belonging to the Federated States of Micronesia in 2017. Between 2015 and 2016, more than 1,300 articles were published, and by February 2016, the World Health Organization (WHO) identified the circulation of ZIKV with criteria for a health emergency (Etienne et al., 2017). One year later, 48 American countries and territories had already registered the circulation of the virus (Etienne et al., 2017).

In 2015, the Brazilian public health authorities declared a national public health emergency and intensified the control campaign with respect to the $A$. aegypti vector in order to confront the ZIKV epidemic. The epidemiological evidence indicated an association between ZIKV infection and the occurrence of deformations and neurological anomalies, such as microcephaly in foetuses of mothers affected by the virus (Menor and Kitron, 2016). The north-eastern region of the country was most affected, especially the states of Bahia, Pernambuco and Rio Grande do Norte. Not surprisingly, the population in these states is mostly poor, living in places that favour the vector and, consequently, the circulation of the virus, which is due to absence of mosquito nets, the ambient climate conditions or both (Barreto et al., 2016).

An evaluation of susceptibility between population groups verifies the idea that Black women are the most vulnerable for mosquito-borne transmission since they are generally housed in the most susceptible regions for this kind of viral diseases and also affected by precarious socio-environmental conditions (Werneck, 2016). The negligence of public institutions promotes the development of an unhealthy environment, characterized by inadequate water supply and sewage systems. In these environments it is easy to identify territories structured on the foundations of environmental racism, that constitute the way in which socio-environmental inequalities occur in different forms for different ethnic groups (Herculano, 2006).

Infections transmitted by vectors occur in different ways in different territories and these moulds the dynamics of transmission. Thus it is important to consider a number of facts, such as the climate, the prospect of locations as breeding grounds, the relationship between the population densities of vectors and humans, the index of local infestation, living conditions, access to sanitation and garbage collection services as well as the history of exposure to infection (Menor and Kitron, 2016).

In addition to these factors, we have an intersectional approach, which, when assessing the interweaving of oppressions, allows the understanding of the different stages of vulnerability, considering the differences between class and race. This is the intersectional approach, a theoretical and methodological model that makes possible a reflection that does not contemplate the hierarchy, but the association or interweaving in the axes of oppression. The concept of intersectionality coined by the American Kimberle Crenshaw (2004) addresses the existence of differences within differences. The author points out that all people experience an intersectional experience, but policies do not consider this aspect. In this sense, it is proposed that research and institutions adopt an intersectional approach to race, class and gender in their discourses and practices about human rights. This approach is fundamental for a real understanding of the epidemiological scenario in view of the inequalities between the different population groups, mainly among Blacks and Caucasians in Brazil and especially in the city of Salvador, whose Black population represents $80 \%$ of the total (IBGE, 2010).

To carry out this evaluation, georeferencing was used for the construction of thematic maps utilized to accomplish the objective of description and visualization of spatial distributions. The maps point to the determined locations and associations between an event and its determinants (Malta et al., 2001; Jakobi, 2008). We embarked on a descriptive exploratory study with a quantitative approach, in which Census Sectors (CS) were used as a spatial analytical unit, defined as the lowest level of spatial aggregation for which periodically updated data is available, related to the demographic structure and social characteristics of the population provided by the Brazilian Institute of Geography and Statistics (Instituto Brasileiro de Geografia e Estatística) (IBGE, 2010).

This study intends to present an exposition of Black and Caucasian, pregnant women through the lens of spatio-temporal distribution of confirmed cases of microcephaly associated with the congenital ZIKV syndrome considering the intersectional approach of race and class in the municipality of Salvador, Bahia in 2015 and 2016.

\section{Materials and Methods}

\section{Study area}

The study was conducted in the municipality of Salvador, Bahia, Brazil focusing on the metropolitan region of the city of Salvador, which currently is composed of 2,675,656 inhabitants distributed through 12 sanitation districts (SDs). The territory covers $692,820 \mathrm{~km}^{2}$, which corresponds to a population density of $3,859.44 / \mathrm{km}^{2}$ according to IBGE (2010).

\section{Database}

The database used was composed by confirmed cases of microcephaly and other neurological malformations associated with the congenital ZIKV syndrome related to both Black and Caucasian pregnant women in the period 2015-2016. This information was made available from the notification sheets kept by the Municipal Secretary of Health of Salvador via the Directory of Epidemiological Vigilance. Duplicate or incomplete notifications were discarded. The variables used for the evaluation were 
grouped by socio-demographics and health assistance (Table 1).

The Digital Cartographic Base (DCB) of the urban area of Salvador was provided by IBGE (2010) in shapefile format at the scale of 1:2000, with an urban mesh constituted of 3,549 CSs.

The software ArcGis 10.1 (ESRI, Redlands, CA, USA) was used together with the DCB of the city of Salvador, the referent addresses of confirmed cases of microcephaly associated with ZIKV and the Living Conditions Index (LCI).

All georeferencing was done according to the Mercator Transverse Universal Projection (MTU) coordinates using Global Positioning System (GPS) available in Google Earth.

The CSs were classified following the living conditions of their respective populations, the LCI was calculated as developed by Paim et al. (2003), who used five proxy variables to living conditions selected from the 1991 demographic census: income (proportion of heads of households in permanent private households, with average monthly income equal to, or less, than the minimum wage); favela (percentage of houses in urban agglomerations)); education (proportion of illiterate people aged 10 to 14); sanitation (percentage of households with access to piped water supply); and crowding (number of residents per room). However, it was neces- sary to make adjustments to the favela and resident/room indices, using the available data from the demographic censuses from 2000 to 2010. Thus, the variable number of households in subnormal clusters, which represented the numerator of the favela indicator, was obtained from the variable type of sector that, in the last two censuses, represented the CS of the subnormal special agglomerate type. Regarding the resident/room indicator, the average number of rooms per household and average number of bedrooms per household variables did not exist in the aforementioned censuses and were replaced by permanent private households and residents in permanent private households, making it possible to calculate the ratio of the number of persons per household. Since the number of rooms serving as bedrooms is not available by the CS for the year 2000 , this final indicator was replaced by the number of residents per bed. But since the number of beds per household per CS was not available, an approximation was made assuming that the proportion of beds per household in each CS in 2000 was the same as that observed in 1991. The favela, income, and resident/bed indicators were organized in ascending order, with those of education and sanitation in descending order. In this sequence, they received a score of consecutive values, starting according to the position

Table 1. Categorization of Study Variables.

\begin{tabular}{|c|c|c|}
\hline Variable & Definitions, Methodology and Approach & Category \\
\hline Race & Self-declaration & Black or Caucasian \\
\hline Age & Self-declaration & Not applicable \\
\hline Neurological anomaly & $\begin{array}{l}\text { Microcephaly } \\
\text { Microcephaly with other CNS* anomaly } \\
\text { CNS*anomalies without microcephaly }\end{array}$ & $\begin{array}{l}\text { 1. Microcephaly } \\
\text { 2. Microcephaly with CNS* anomaly } \\
\text { 3. CNS* anomalies without microcephalia } \\
\text { 4. No information }\end{array}$ \\
\hline Arbovirus infection & $\begin{array}{l}\text { Dengue } \\
\text { Zika } \\
\text { Chikungunya }\end{array}$ & $\begin{array}{l}\text { 1. Chikungunya } \\
\text { 2. Dengue } \\
\text { 3. Chikungunya and dengue } \\
\text { 4. None of these infections } \\
\text { 5. Unsure } \\
\text { 6. No information }\end{array}$ \\
\hline Syphilis & Serology & $\begin{array}{l}\text { 1. Negative } \\
\text { 2. Positive } \\
\text { 3. Not realized } \\
\text { 4. No information }\end{array}$ \\
\hline Toxoplasmosis & Serology & $\begin{array}{l}\text { 1. Negative } \\
\text { 2. Positive } \\
\text { 3. Not realized } \\
\text { 4. No information }\end{array}$ \\
\hline Zika infection & Serology & $\begin{array}{l}\text { 1.Yes } \\
\text { 2. No } \\
\text { 3. No information }\end{array}$ \\
\hline TORCH** & Serology & $\begin{array}{l}\text { 1. Yes } \\
\text { 2. No } \\
\text { 3. Unsure }\end{array}$ \\
\hline Exanthema & Symptomatology & $\begin{array}{l}\text { 1. Yes } \\
\text { 2. No } \\
\text { 3. Unsure }\end{array}$ \\
\hline Fever & Symptomatology & $\begin{array}{l}\text { 1. Yes } \\
\text { 2. No } \\
\text { 3. Unsure }\end{array}$ \\
\hline
\end{tabular}

${ }^{*}$ Central nervous system; ${ }^{* *}$ cluster of symptoms caused by congenital infection with a number of various infections, e.g., cytomegalovirus, herpes simplex, parvovirus, rubella, syphilis, toxoplasmosis, varicella zoster and zika virus. 
assumed in this ordering. These scores were organized in ascending order and grouped in quartiles of relatively homogenous CS, corresponding to population strata classified as having high; intermediate; low; and very low living conditions, and then represented on the thematic map.

\section{Statistical Analysis}

The analysis of the data generated by the notification pages was conducted via SPSS, version 21 (IBM), utilizing simple and relative frequencies. The analysis of density in order to identify hotspots was conducted using the kernel density estimator, implemented through the spatial analyst extension of the ArcGIS programme, utilizing the quartz smoothing function 13. A bandwidth of $1 \mathrm{~km}$ was defined, from which surfaces were constructed for the cases for the population and for the ratio between the densities of the cases and population (kernel ratio) the latter being an approximation of the risk areas, since their values are weighted by the case/population relationship.

\section{Results}

The municipality of Salvador registered the highest percentile (46.4\%) of confirmed cases of CZS in the State of Bahia. During the study period, 668 notifications were registered, out of which six notifications were discarded as duplicates. In 2015, 271 cases were notified, while 2016 saw an increase of 391 notifications.

According to the final classification criteria, 34.3\% (227/662) referred to confirmed cases of microcephaly associated with the congenital syndrome of ZIKV. Almost 47.1\% (312/662) of the cases were discarded after investigation to verify that there is no association of the neurological alteration of the children with the occurrence of ZIKV infection by the mother, with $11.3 \%(75 / 662)$ remaining under investigation, while there were no classification records for $7.3 \%$ (48/662) of the notifications. With regard to the confirmed cases, $21.9 \%(50 / 227)$ of the children born had microcephaly, while $67.1 \%(153 / 227)$ presented microcephaly with alterations because of CZS, 7\% (16/227) presented without microcephaly, while there were there was no specification for the type of alteration encountered in $3.9 \%(9 / 227)$ of the notifications. With respect to the question of race, 36 notification files were discarded because of lack of information. Thus, there were 191 notification files available for the evaluation of spatial distribution associated with living conditions. The database's evaluation yielded the observation that $91 \%$ of the pregnant women were Black, and only $8,9 \%$ Caucasian. An analysis of the data revealed that Caucasian women received more prenatal examinations, which increased accessibility to tests and results for communicable diseases and, consequently, a healthcare intervention in a timely manner, where necessary. In relation to the completion of data forms, a difference in the information provided in the notifications was identified, as can be observed in the items without information, in relation to toxoplasmosis and zika tests, according to Table 2. It was found that Caucasian women did not present any history of arbovirus infection, while Black women demonstrated histories of both dengue and chikungunya (Figure 1).

Table 2. Proportional distribution between Black and Caucasian women with reference to various infections.

\begin{tabular}{lcc}
\hline Examination & Caucasian women (\%) & Black women (\%) \\
TORCH & & \\
Yes & 100 & 92,5 \\
No & - & 2,3 \\
Uninformed & - & 5,2 \\
ZIKA & & \\
Yes & 17,6 & 15,5 \\
No & 29,4 & 15,0 \\
Uninformed & 53,0 & 69,5 \\
\hline Toxoplasmosis (Result) & & \\
Negative & 100 & 82,2 \\
Positive & - & 2,3 \\
Not realized & - & 2,9 \\
No information & - & 12,6 \\
Syphilis (Result) & & \\
Negative & 88,2 & 82,2 \\
Positive & 11,8 & 3,4 \\
Not realized & - & 2,3 \\
No information & - & 12,1 \\
\hline
\end{tabular}

Examinations completed during the prenatal period between 2015 and 2016 in the city of Salvador, Bahia.

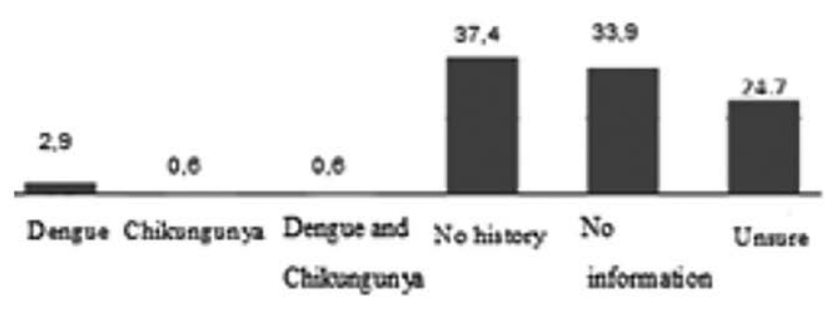

Black pregnant woman

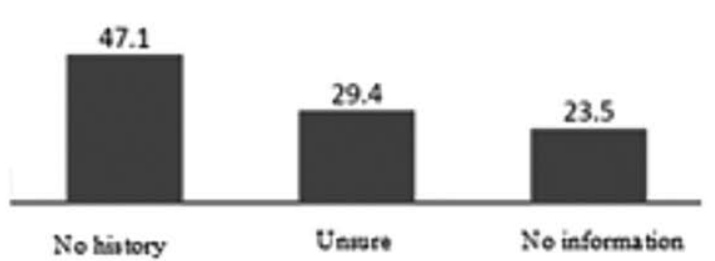

Caucasian pregnat woman

Figure 1. Difference between Black and Caucasian pregnant women with reference to previous arbovirus infections. Examinations completed during the prenatal period between 2015 and 2016 in the city of Salvador, Bahia. 
Kernel analysis identified the density of cases associated with CZS (Figures 2 and 3). Data evaluation showed that there was a difference in the distribution of CZS cases within the territory according to the variation of the LCI and the territory (Table 3).

The analysis of spatial distribution of the LCI allowed identification of areas with the highest concentration of microcephaly associated with CZS and the socio-environmental conditions of each census sector, with a record of occurrence (Figure 4). When considering the distribution of the SDs, it was observed that these areas are distributed over four (4) districts and eleven (11) neighbourhoods of the city: SD of São Caetano/Valéria (Marechal Rondon, Campinas de Pirajá, São Caetano, and Boa Vista de São
Table 3. Association between presence of microcephaly linked to congenital zika virus infection and the living conditions index (LCI).

\begin{tabular}{lccc} 
Living conditions & $\begin{array}{c}\text { Neighbourhood } \\
\text { (No.) }\end{array}$ & $\begin{array}{c}\text { Black } \\
(\%)\end{array}$ & $\begin{array}{c}\text { Caucasian } \\
(\%)\end{array}$ \\
High & 42 & 9,2 & 35,3 \\
Intermediate & 39 & 24,7 & 29,4 \\
\hline Low & 38 & 31,6 & 23,5 \\
Very low & 39 & 34,5 & 11,8 \\
\hline Total & 158 & 100 & 100 \\
\hline
\end{tabular}

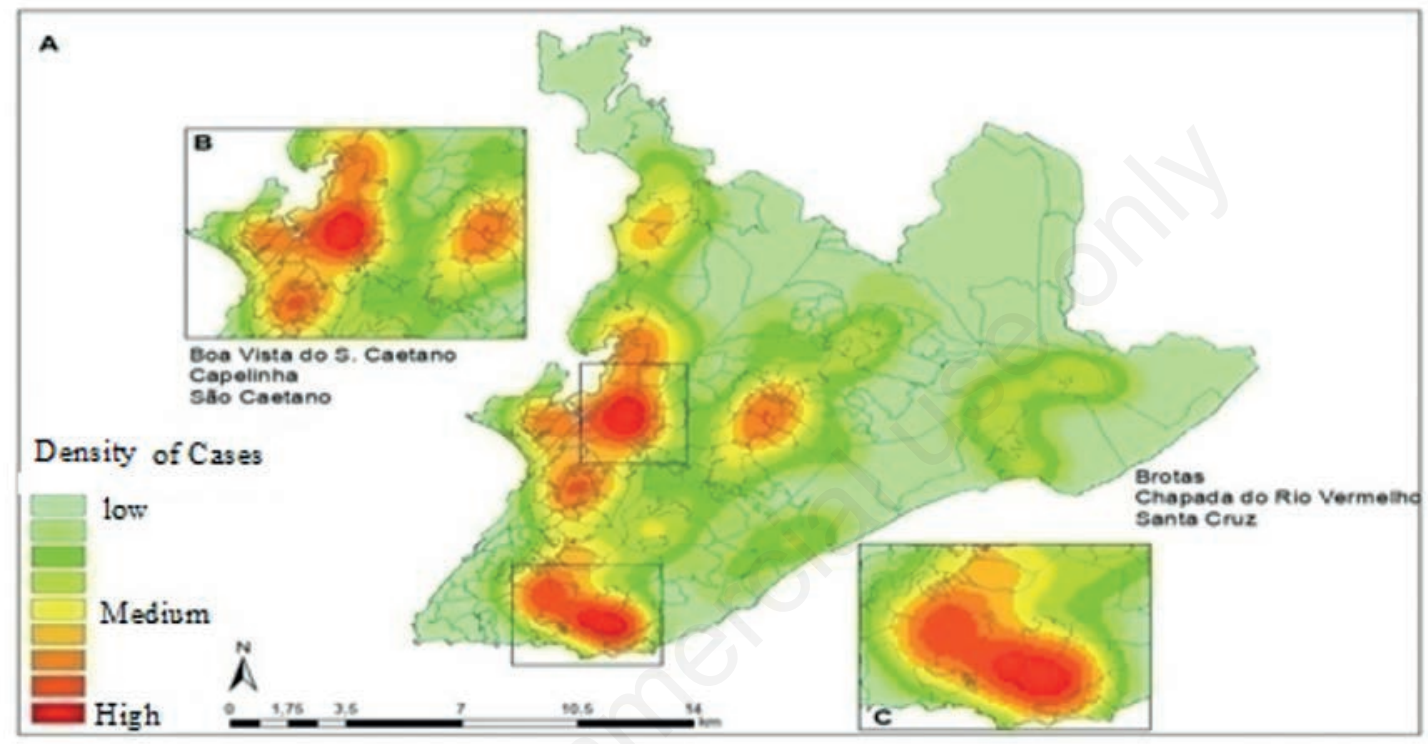

Figure 2. Density of microcephaly cases linked to congenital zika virus infection in children born to Black women. Study covering the prenatal period between 2015 and 2016 in the city of Salvador, Bahia.

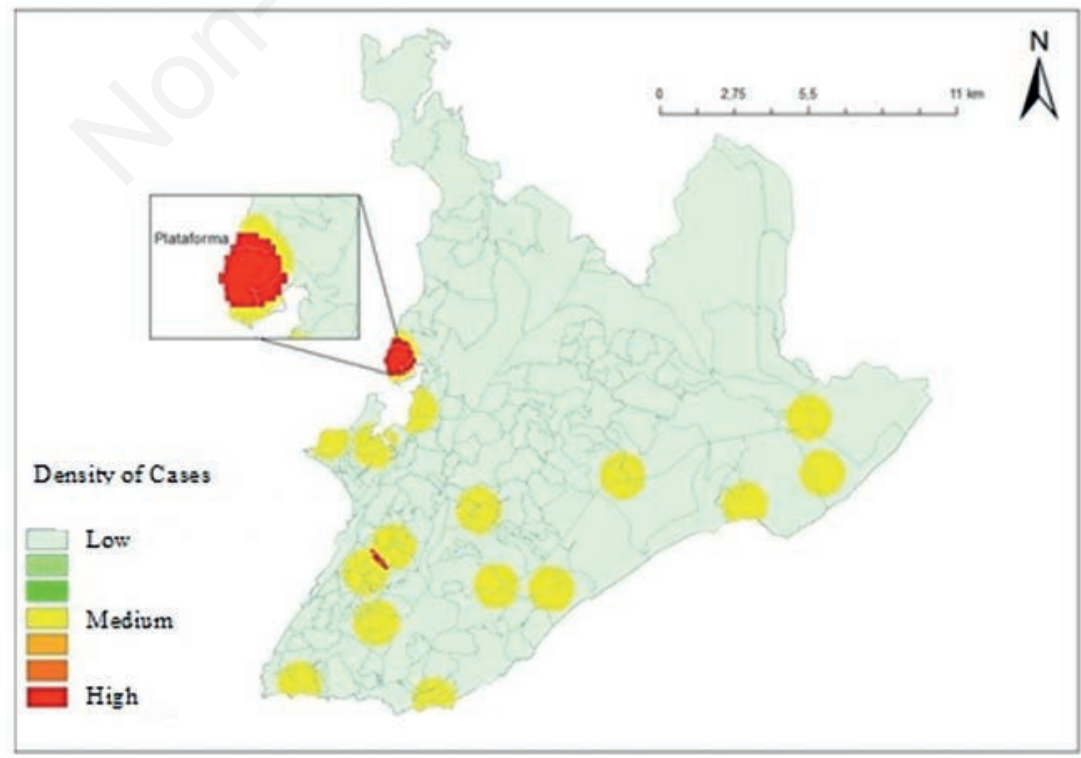

Figure 3. Density of microcephaly cases linked to congenital zika virus infection in children born to Caucasian women. Study covering during the prenatal period between 2015 and 2016 in the city of Salvador, Bahia. 
Caetano), SD of Subúrbio Ferroviário (Lobato and Alto de Coutos), SD of Brotas (Brotas, Cosme de Farias, Acupe de Brotas, Candeal) and SD Barra/Rio Vermelho (Engenho Velho da Federação). The analysis of the spatial distribution, performed using the LCI, allowed us to identify that cases of microcephaly associated with CZS, in Black, pregnant women, were concentrated in CSs with low (31.6\%) and very low (34.5\%) LCI (Figure 5). Cases of Caucasian, pregnant women were concentrated in areas with high (35.6\%) and intermediate (29.4\%) LCI (Figure 6).

Through analysis of the case maps versus the population distribution, the risk areas for Black and Caucasian pregnant women were determined as those where children with CZS-associated microcephaly had been born. Twelve such areas for Black women were identified in the municipality of Salvador (Figure 7). Areas of high risk for Caucasian women were discovered in only two sectors, as observed in Figure 8.

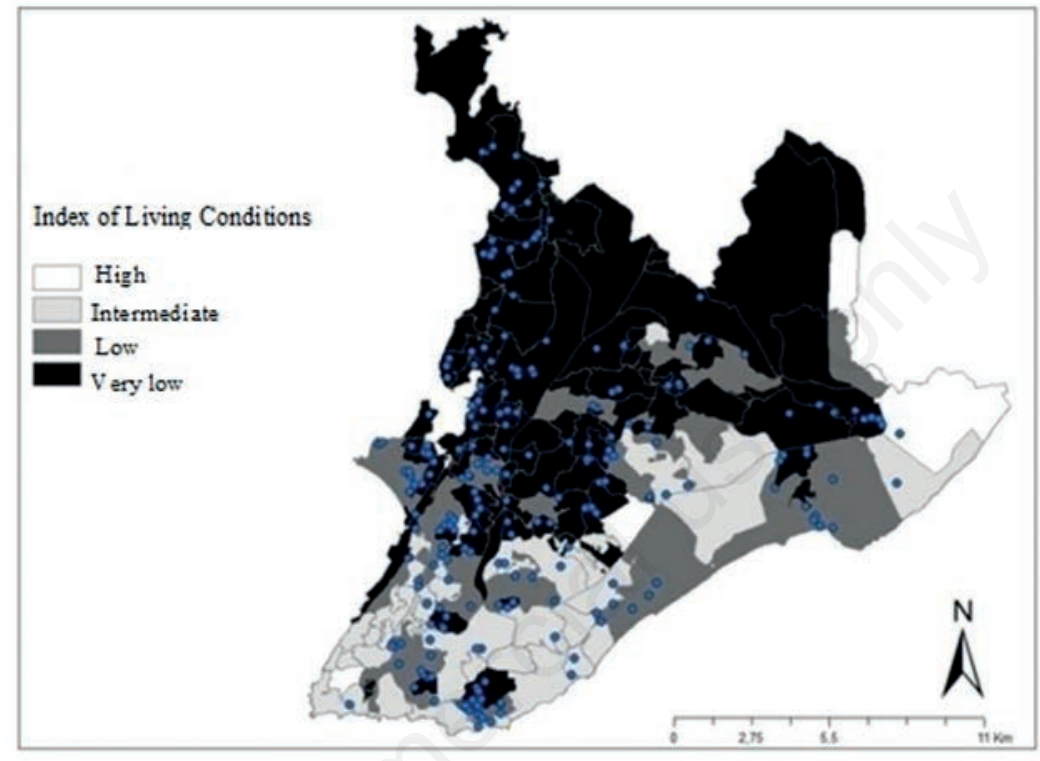

Figure 4. Distribution of confirmed cases of microcephaly linked to congenital zika virus infection. Study covering during the prenatal period between 2015 and 2016 in the city of Salvador, Bahia.

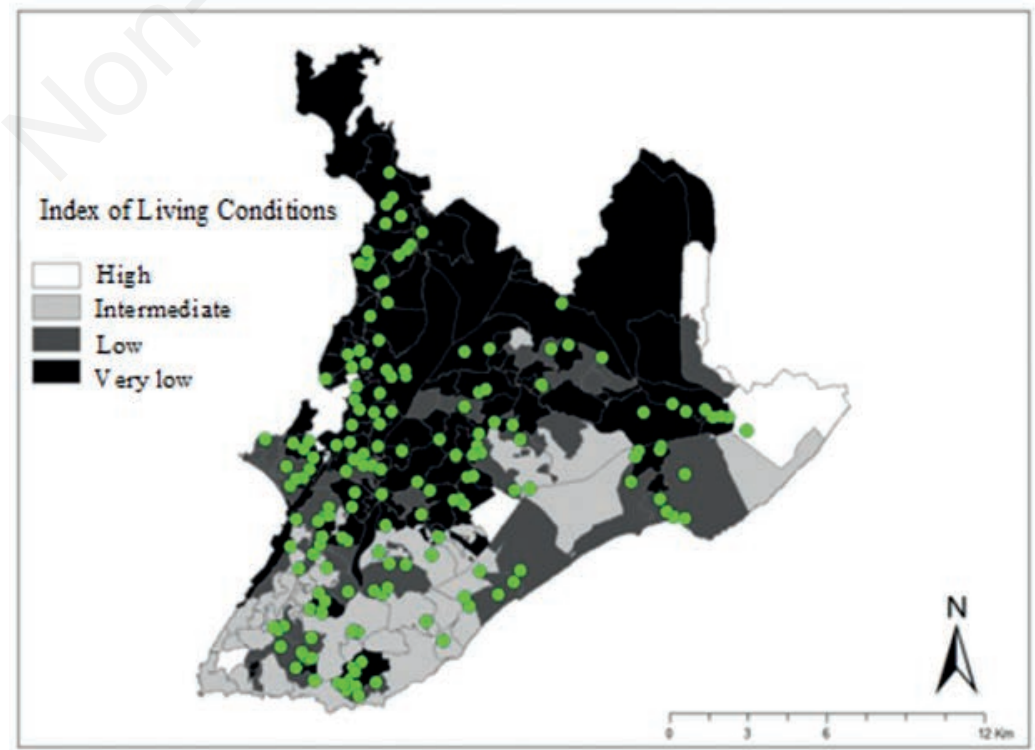

Figure 5. Distribution of confirmed cases of microcephaly, linked to congenital zika virus infection in children of Black, pregnant women. Study covering during the prenatal period between 2015 and 2016 in the city of Salvador, Bahia. 


\section{Discussion}

Thematic maps, fed by the information database, can assist managers and health teams in the planning of interventionary actions, by offering elements contributing to an understanding of the problems of the territories. Analysis of the data reveals an elevated percentile of items without information, which compromises the understanding of the epidemiological panorama in full. This fact accounts for one of the difficulties of completing studies with secondary data.
The findings of a study conducted by Braz et al. (2013) questions the performance of the unified health system (SUS) in reaching ethno-racial equity. In a study with the objective of assessing equity in health services by analyzing the completeness of the race field through the SUS performance index (IDSUS), the authors found that out of the eight health information systems/modules studied, only three could be considered adequate, with more than $90 \%$ of information fields filled, while five, were classified as inadequate. Another important finding in this study concerns the indicators used to build the IDSUS, considering that, out of the 24

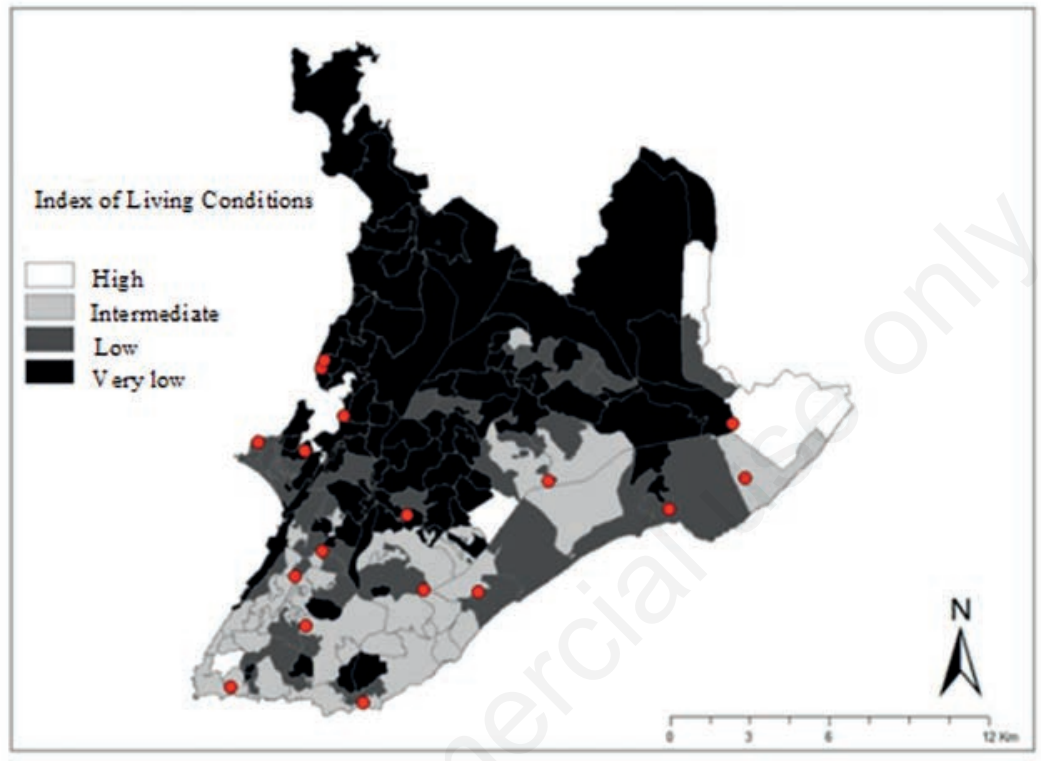

Figure 6. Distribution of confirmed cases of microcephaly, linked to congenital zika virus infection in children of Caucasian, pregnant women. Study covering during the prenatal period between 2015 and 2016 in the city of Salvador, Bahia.

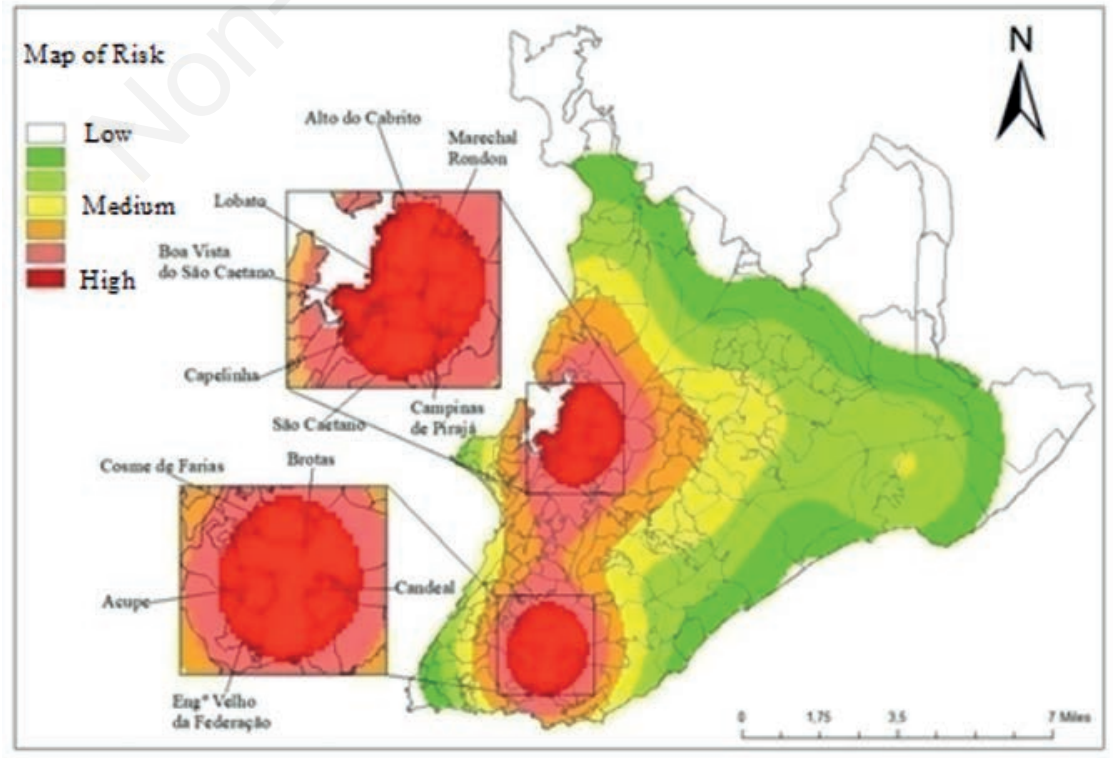

Figure 7. Distribution of high-risk areas for the occurrence of microcephaly cases, linked to congenital zika virus infection in children born to Black women. Study covering during the prenatal period between 2015 and 2016 in the city of Salvador, Bahia. 
indicators, only three were good enough for analysis.

In a study conducted by Silva and Mendes (2016), to evaluate the completion of notification files of dengue, the authors concluded that the fields containing general data obtained $99 \%$ to $100 \%$ completion, while fields referencing race, schooling, and SUS card numbers presented lower completion ratings of $45.5 \%, 47.31 \%$, and $0.45 \%$, respectively. As we had similar, even lower, results in this respect, the conclusion must be that the fragility of the records, even in an epidemic period, prevents an assertive action towards equity, considering that a recognition of differences is needed to allow identification of the real needs of population groups, relating especially to the formulation and monitoring of public policies that meet the demands of specific population groups.

The analysis of this study presented by the statistical analysis is related to the population proportion of Causians and Blacks in the region of study. The Black population represents half of the Brazilian population; however, in the city of Salvador, this population corresponds to $80 \%$ of the locals. Although this segment is the majority, these people have poor living conditions compared to the Caucasian population, so the data point toward the need to consider the social determinants of health in the elaboration of public intervention policies.

The proposal was to show that there is a structural issue of vulnerability that differentiates the condition of risk exposure among different people. The Black population is composed of people with black or brown skin according to IBGE (2010); in the study we considered cases reported among Black mothers (brown + black $=$ $2.869 .141 / 3.573 .973=80 \%)$ and Caucasian $($ Caucasian $=$ $643.539 / 3.573 .973=18 \%$ ). Public institutions that neglect these specificities reaffirm the existence of institutional racism (Filho, 2012) Thus, although there was an imbalance between the percentage of Caucasian, pregnant women $(8.9 \%)$ and Black, pregnant women $(90 \%)$ affected, the latter were the most vulnerable in the proportional evaluation of the groups, in relation to examinations, history with arboviruses, percentage of registrations without information, and greater awareness of the patients about possible symptoms (exanthema and fever).

The study conducted by Tomasi et al. (2017), with the intention to evaluate the quality of prenatal basic care in all of Brazil, found a significant difference between 4,111 (67.5\%) women considered of "mixed" race and 1,983 (32.5\%) Caucasian women: among six evaluation indicators for prenatal characterization, Black, pregnant women had less acceptable results, with a quality of care coverage of $14.9 \%$ versus $15.3 \%$ of Caucasian, pregnant women. In an evaluation of the disparities between 566 Black and Caucasian pregnant women in the United States, it was observed that $78.1 \%$ were Caucasian, while $21.9 \%$ were Black. In this study, even with an inverted percentage in relation to other studies, Black, pregnant women had the least acceptable indicators in relation to Caucasian, pregnant women; most were pregnant adolescents and young people with low income, with a lower probability of employment and who depended on public assistance since they had less access to health insurance. The research showed that Black women were disadvantaged before, during and after pregnancy, with the highest probability of having the birth defects that affect the health of newborns as also pointed out by Clay et al. (2018). In an epidemic period for CZS, in which a patient is part of a group at risk, it is expected that greater appropriation of care will be provided, as well as closer attention, to these pregnant women regarding the quality of information. These data permit an inference about the quality of care provided, as well as the education of these pregnant women, regarding the appropriation of care and access to health services, which can be reiterated by pre-existing data. The Annual Report on Racial Inequality (2010) reports that, among Brazilian women evaluated in relation to schooling, Caucasian women represented $0.8 \%$ of the group without any kind of formal education, while Black women represented $2.7 \%$; and for those with twelve years or more of study, 20.7\% were

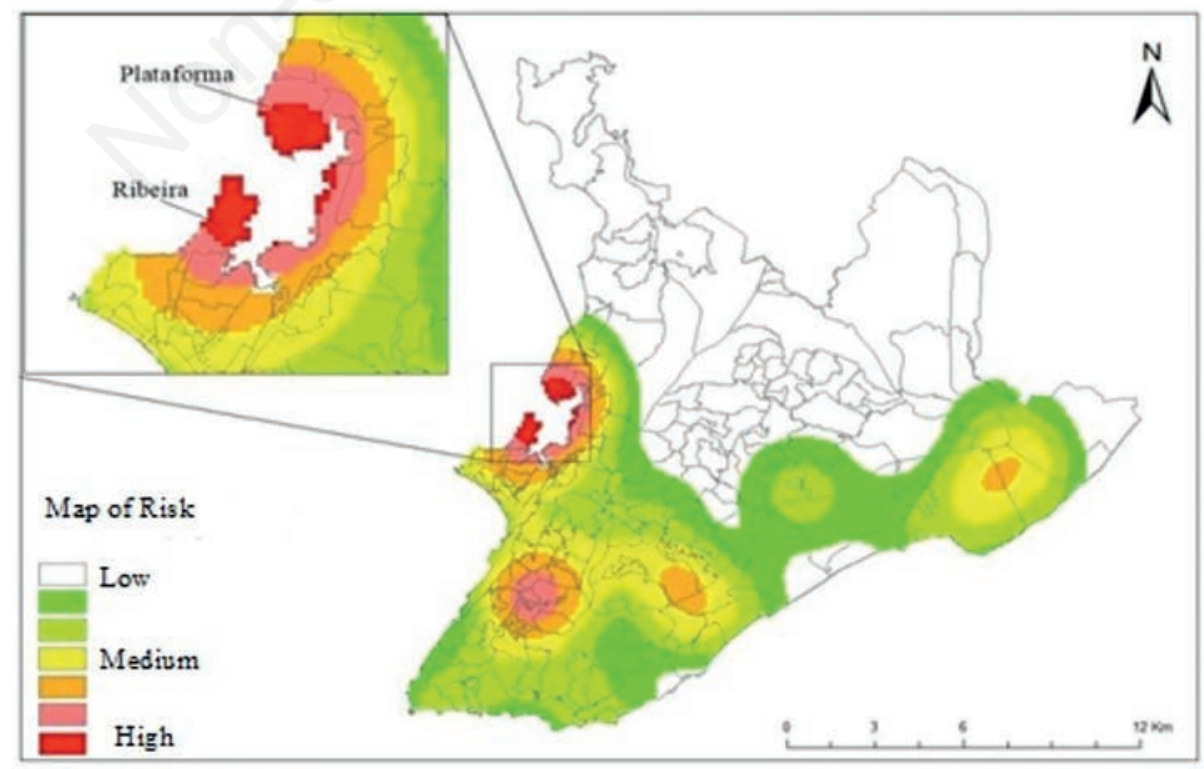

Figure 8. Distribution of high-risk areas for the occurrence of microcephaly cases, linked to congenital zika virus infection in children born to Caucasian women. Study covering during the prenatal period between 2015 and 2016 in the city of Salvador, Bahia. 
Caucasian and $8.9 \%$ Black. Furthermore, $71.0 \%$ of Caucasian, pregnant women received more than seven consultations, in comparison to just $42.6 \%$ of Black women (Paixão et al., 2010).

In a study conducted in the municipality of Salvador, Domingues et al. (2013) identified, through interviews with users of public health services, that discriminatory practices interfered with the quality of attention given by health professionals. This evaluation considered a difference in the time of care offered Caucasian and Black women, as well as the accomplishment of exploratory examinations through touch, and the quality of the information provided. These findings are similar to those of Tomasi et al. (2017) in that they found that low-income women obtained less information and that pregnant women living in areas with high Human Development Index (HDI) received more information from health professionals.

To understand the occurrence of arboviruses in urban environments, it is necessary to consider the territorial configuration, in order to perceive the inequalities to which different population groups are exposed through the expression of social determinants. In this sense, discussing the environmental issue from the perspective of environmental justice favours the understanding of specific population needs, understanding that environmental problems affect different groups in different ways, because of their ethnic, racial and gender characteristics. (Paim, 2003; Paixão, 2004)

The International Certificate of Vaccination was created by the WHO, with the purpose of evaluating, on a territorial basis, the socioeconomic and environmental conditions of population groups associated with the occurrence of diseases and health problems. The integration of geoprocessing technologies into the health sector is necessary to better portray the spatial arrangement of sanitation districts. In this sense, Geographical Information Systems (GIS) software has the ability to process large quantities of information, referencing a determined area or region, making it possible to cross-reference information, observe the interactions of multiple variables, simulate systems in order to predict events, and respond to the questions of numerous surveys (Gurgel, 2004; Bavia et al., 2001). To demonstrate the social inequalities concerning perinatal mortality in Salvador, Nascimento (2014) conducted a study of spatial aggregates, using LCI as indicator of a synthesis of living conditions, such as "better", "intermediate" and "poor living conditions". The author concludes that neo-mortality is higher in the intermediate LCI stratum. In all three strata, the biggest proportion of new-borns were Black. More than half of the mothers, in all three strata, underwent less than seven prenatal consultations, while the biggest proportion of public and private practices were encountered in the highest strata of LCI, while in the lowest LCI, there was only one public practice.

In mapping the spatial distribution of reported cases of the acquired Immunodeficiency Syndrome (AIDS) in adults in the city of Campinas, São Paulo, Stephan et al. (2010) found that the female AIDS cases were concentrated in areas with poor living conditions, while men with AIDS were mainly in areas with low LCI and high crime. The results obtained by the analysis of this indicator could contribute to the development of public actions, according to the needs of each location, which could help combat the gaps identified in public assistance.

Our analysis of the spatial distribution of CZS cases in the municipality of Salvador revealed that Black women live under the least acceptable conditions (with $31.6 \%$ of cases with low LCI and $34.5 \%$ with very low LCI), while Caucasian women (with $35.3 \%$ of cases with high LCI and $29.4 \%$ with intermediate LCI) had a better situation. We found that all women in our study group were susceptible to illness; however, Black women become ill in scenarios of increased exposure and vulnerability. They are, therefore, under conditions of cyclical inequality, which generates a pattern that defines different ways of living, becoming sick and dying.

The CSs that represent areas of higher risk are concentrated in neighbourhoods that are considered peripheral. However, it is worth noting that the quality of the LCI varies even in peripheral areas, but what remains consistent is that Caucasian pregnant women, even in a lower sample size, live in areas with the best indicators. Thus, it seems that 'whiteness' in a way serves as a protective factor against risk exposure.

The LCI aggregates data on schooling, income, housing, sanitary sewage, and person per bedroom. These variables determine the risk of exposure to arboviruses, CZS among them, through the Ae. aegypti vector. According to Roque et al. (2017), efforts aimed at coping with dengue, yellow fever, chikungunya and zika are associated with investment in urban infrastructure and activities aimed at reducing poverty and population density.

Privilege binds various sectors together, as can be observed in the historical series by Marcondes et al. (2013). In the period between 1995 and 2009, Black women had a lower life expectancy than Caucasian women, which was evaluated by calculating the number of Black women aged 60 or above. It was found that the percentage of older Black women had actually fallen from $14 \%$ to 10.3\% between 1995 and 2009 Marcondes et al. (2013). As for income, it was pointed out that Black women received $51 \%$ of what Caucasian women received. Families with Black women as head-of-household were always worse off, followed by Black men, Caucasian women, and Caucasian males.

In this context, public institutions that ignore these specificities reaffirm the existence of institutional racism. Institutional racism is defined as "a failure of institutions and organizations to provide adequate, professional service to particular groups of people in virtue of their colour, culture, and racial or ethnic origins". (CRI, 2006, p.15). This is certainly present in relation to the occurrence of CZS, which is more common in Black women due to systematic institutional neglect. It is clear that the "low" and "very low" categories of the LCI, in which socioeconomic and environmental variables are compiled, directly interfere with the rates of exposure and illness in the population. Thus, through the iniquity in health observed in this study, the need for a new term, i.e. "sanitary racism", arises when referring to the scenario of systematic health vulnerability to which the Black population is subjected.

\section{Conclusions}

Living conditions are directly associated with different forms of vulnerability. Black women experience cruel and unjust forms of greater exposure to the risk of disease, as they are deprived of rights via precarious housing, insufficient income and reduced access to education. Racism, as a social construct, traverses all institutional spheres and connects iniquities. Intersectionality, in this sense, allows us to understand how this oppressive web that vilifies Black women and their families is established. The spatial dispersion of cases of microcephaly is associated with paints a portrait of the multiple oppressions which Black women are subject to, proving that the territory is alive and represents the varying experiences of privilege and oppression. The unified health system, insofar as it advocates as a principle, must find ways to dia- 
logue and generate an inter-institutional scenario, since $80 \%$ of the Brazilian population depend on it as a primary form of health care and promotion.

\section{References}

Bavia ME, Malone JB, Hale L, Dantas AF, Marroni L, Reis R, 2001. Use of thermal and vegetation index data from earth observing to evaluate the risk of Schistosomiasis in Bahia, Brazil. Acta Tropica 79:79-85.

Braz RM, Oliveira PT, Reis AT, Machado NMS, 2013. [Avaliação da completude da variável raça/cor nos sistemas nacionais de informação em saúde para aferição da equidade étnico-racial em indicadores usados pelo índice de desempenho do sistema único de saúde.] Saúde Debate 37:554-62. [Article in Portuguese].

Clay SL, Griffin, M, Averhart W, 2018. Black/White disparities in pregnant women in the United States: An examination of risk factors associated with Black/White racial identity. Health Soc Care Community 26:654-63.

Combate ao Racismo Institucional - CRI, 2006. Identificação e abordagem do Racismo Institucional. Articulação de Combate ao Racismo Institucional, 145pp.

Crenshaw K, 2004. A interseccionalidade na discriminação de raça e gênero. In: VV.AA. Cruzamento: raça e gênero 7-16.

Domingues PML, Nascimento ER, Oliveira JF, Barral FE, Rodrigues QP, Santos CCC, Araújo EM, 2013. [Discriminação racial no cuidado em saúde reprodutiva na percepção de mulheres.] Texto Contexto Enferm 22:285-92. [Article in Portuguese].

Etienne C, Santos T, Espinhal MA, 2017. Keynote Address (November 2016) Zika Virus Disease in the Americas: A Storm in the Making. Am J Trop Med Hyg 97:16-8.:

Filho MAS, 2012. O recorte racial nos Sistemas de Informação em Saúde do Brasil: Potencialidades para a tomada de decisão. Saúde da população negra, 372 pp.

Gurgel-Gonçalves R, Duarte MA, Ramalho ED, Palma ART, Romaña CA, Cuba-Cuba CA, 2004. [Distribuição espacial de populações de triatomíneos (Hemiptera: Reduviidae) em palmeiras da espécie Mauritia flexuosa no Distrito Federal, Brasil.] Revista da Sociedade Brasileira de Medicina Tropical 37: 241-7. [Article in Portuguese].

Herculano S, Pacheco T, 2006. [Racismo Ambiental. I Seminário Brasileiro contra o Racismo Ambiental.] [Article in Chinese]. Instituto Brasileiro de Geografia e Estatística. IBGE, 2010. Available from: https://censo2010.ibge.gov.br

Jakobi HR, 2008. [Mapa de risco ocupacional no Estado de
Rondônia baseado em tecnologia de georeferenciamento.] Dissertação 96pp. [Article in Portuguese].

Johansen IC, 2014. [Urbanização e saúde da população: o caso da dengue em Caraguatatuba.] Dissertação 148 pp. [Article in Portuguese].

Marcondes MM, Pinheiro L, Queiroz C, Querino AC, Valverde D, 2013. [Dossiê mulheres negras: retrato das condições de vida das mulheres negras no Brasil.] Ipea 160 pp. [Article in Portuguese].

Menor J, Kitron U, 2016. [Uma geografia social do zika no Brasil.] Estudos Avançados 30:167-75. [Article in Portuguese].

Nascimento RCS, 2014. [Mortalidade perinatal em Salvador: análise espacial das condições de evitabilidade e desigualdades sociais.] Tese de doutorado $77 \mathrm{pp}$. [Article in Portuguese]

Paim JS, Silva LM, Costa MCN, Prata PR, Lessa I, 2003. [Desigualdades na situação de saúde do município de Salvador e relações com as condições de vida.] R Ci Méd Biol 2:30-9. [Article in Portuguese].

Paixão M, 2004. [O verde e o negro: a justiça ambiental e a questão racial no Brasil.] In Justiça ambiental e cidadania, 315 pp. [Article in Portuguese].

Paixão M, Rossetto I, Montovanele F, Carvano LM, 2010. Relatório Anual das Desigualdades Raciais no Brasil, 3:79117

Roque DM, Almeida FM, Moreira VS, 2017. [Política Pública de combate à dengue e os condicionantes socioeconômicos. Encontro Brasileiro de Administração Pública, 16pp.] Available from: http://www. ufpb.br/ ebap/ contents/ documentos/ 0665-680- politica- publica- de-combate-a-dengue-e-oscondicionantes-socioeconomicos.pdf. [Article in Portuguese].

Silva LS, Mendes DRG, 2016. [Completude do sistema de informação de agravos de notificação de dengue em Valparaíso de Goiás, 2012- 2015.] Rev Cient Sena Aires 5:105-16. [Article in Portuguese].

Stephan C, Henn CA, Donalisio MR, 2010. [Geographic expression of AIDS epidemic in Campinas, Southeastern Brazil, between 1980 and 2005.] Rev Saúde Pública 44:812-9. [Article in Portuguese]

Tomasi E, Fernandes PAA, Fischer T, Siqueira FCV, Silveira DS, Thumé E, Duro S MS, Saes MO, Nune BP, Fass AG, Facchini LA, 2017. [Qualidade da atenção pré-natal na rede básica de saúde do Brasil:indicadores e desigualdades.] Cad Saúde Pública 33:1-11. [Article in Portuguese].

Werneck J, 2016. [Epidemia de zika vírus e as mulheres negras.] Available from: http://www.geledes.org.br/a-epidemia-dezika-virus-e-as-mulheres-negras-2o-dados- nao-oficiais-70bebes-com-microcefalia-sao-filhos-de-negras/\#gs.6GW80Ow. [Article in Portuguese]. 